\title{
Increased Iron-Carbon Interactions Under Long- Term Acid Deposition Enhance Soil Organic Carbon Sequestration in A Tropical Forest in Southern China
}

\section{Jingwen Chen}

South China Botanical Garden

Yuanliu Hu

South China Botanical Garden

Steven J. Hall

lowa State University

Dafeng Hui

Tennessee State University

Jianling Li

South China Botanical Garden

\section{Guoyin Chen}

South China Botanical Garden

Lianwei Sun

South China Botanical Garden

\section{Deqiang Zhang}

South China Botanical Garden

Qi Deng ( $\sim$ dengqi@scbg.ac.cn )

South China Botanical Garden https://orcid.org/0000-0001-8208-9763

\section{Research Article}

Keywords: Acid deposition, Oxisol, Iron oxides, mineral-associated carbon, soil pH, tropical forest

Posted Date: June 8th, 2021

DOl: https://doi.org/10.21203/rs.3.rs-570953/v1

License: (c) (i) This work is licensed under a Creative Commons Attribution 4.0 International License. Read Full License 


\section{Abstract}

Atmospheric acid deposition remains a widespread problem that may influence the protection of carbon (C) in soil by altering organo-mineral interactions. However, the impacts of additional acidity on organomineral interactions and soil $\mathrm{C}$ sequestration in naturally acidic tropical soils with a high content of reactive iron $(\mathrm{Fe})$ phases have not been well studied. Here we sampled a nearly 10-yr field experiment with a gradient of acidity treatments $\left(0,9.6,32,96 \mathrm{~mol} \mathrm{H}^{+} \mathrm{ha}^{-1} \mathrm{yr}^{-1}\right.$ as nitric acid + sulfuric acid) to examine how acidification alters organo-mineral interactions and soil organic carbon (SOC) pools in a tropical forest in southern China. As expected, soil acidification significantly enhanced the leaching of base cations (e.g., $\mathrm{Ca}^{2+}$ ), and it also altered the solubility and composition of Fe and Al phases. The acidity treatments converted more crystalline Fe (oxyhydr)oxides to short-range-ordered phases, resulting in a large increase in Fe-bound C vs. a relatively small decrease in Ca-bound C. Overall, the acidity treatments increased the mineral-associated C stock to $32.5-36.4 \mathrm{Mg} \mathrm{Cha}^{-1}$ vs. $28.8 \mathrm{Mg} \mathrm{Cha}^{-1}$ in the control, accounting for $71-83 \%$ of the observed increase in total SOC stock. These findings highlight the importance of $\mathrm{pH}$-sensitive geochemical changes and the key roles of $\mathrm{Fe}$ in regulating the response of SOC to further inputs of acid deposition even in highly weathered and naturally acidic soils. The magnitude of SOC changes observed here indicates the importance of including $\mathrm{pH}$-sensitive geochemistry in Earth system models to predict ecosystem $\mathrm{C}$ budgets under future acid deposition scenarios.

\section{Introduction}

Since the industrial revolution, human activities such as fossil-fuel combustion and the use of chemical fertilizer have greatly increased nitrogen $(\mathrm{N})$ and sulfur $(\mathrm{S})$ inputs as acid rain into the terrestrial biosphere (Likens et al. 1996; Galloway et al. 2008). These acid inputs have significant effects on the function and structure of natural ecosystems (Vitousek et al. 1997). In particular, long-term acid deposition can aggravate soil acidification, which has multiple biological and geochemical impacts on soil biogeochemical cycles (Bowman et al. 2008; Meng et al. 2019). However, the net effects of acidification on the multiple biological and geochemical processes that influence soil organic carbon (SOC) cycling are complex (Averill and Waring 2018; Ye et al. 2018), and reconciling the multiple competing impacts of acidification on SOC remains an important knowledge gap with important implications for biogeochemical models.

Recent studies and conceptual frameworks underscored the importance of acid-sensitive organo-mineral interactions in regulating soil carbon (C) dynamics (Averill and Waring 2018). Soil pH plays a central role in understanding the multiple potential impacts of acidification on soil C. For example, in alkaline soils buffered by calcium carbonate (inorganic $\mathrm{C}$ ), $\mathrm{N}$-induced soil acidification accelerates calcium carbonate

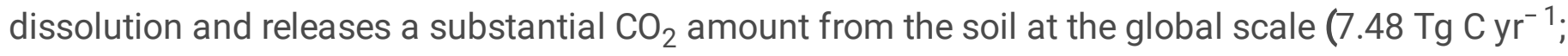
Zamanian et al. 2018). In Chinese croplands, Raza et al (2020) estimated a 7\% (0.15 Pg C; $1.1 \mathrm{Mg} \mathrm{C}^{-}$ha $^{-}$

$\left.{ }^{1}\right)$ loss of carbonate $C$ due to soil acidification from 1980 to 2020 . In soils with alkaline to circumneutral 
$\mathrm{pH}$, electrostatic bridging between soil organic matter and clay mineral surfaces by divalent base cations $\left(\mathrm{Ca}^{2+}, \mathrm{Mg}^{2+}\right)$ provides a primary mechanism of physico-chemical protection for SOC (Rasmussen et al. 2018; Yu et al. 2021). In these alkaline to circumneutral soils, inputs of acidity $\left(\mathrm{H}^{+}\right)$are mostly buffered by replacement of base cations on ion exchange sites (Chadwick and Chorover 2001; Kirk et al. 2010), possibly releasing SOC bound to clay minerals via divalent cations. However, in acidic soils, exchangeable base cation concentrations are typically much lower, divalent cation bridging is less important for SOC protection (Rasmussen et al. 2018; Yu et al. 2021), and soil acidity is mainly buffered by the dissolution of silicates and aluminum (Al)- or iron (Fe)-bearing minerals (Johnson 2002; Ross et al. 2008; $\mathrm{Li}$ and Johnson 2016). The release of hydrolyzing cations (e.g., $\mathrm{Fe}^{3+}$ and $\mathrm{Al}^{3+}$ ) at low pH may favor subsequent formation of organo-mineral complexes through ligand exchange between carboxyl groups of organic matter and singly coordinated inorganic hydroxyl groups at mineral surfaces (Kaiser and Guggenberger 2000; Mueller et al. 2012). Consistent with these ideas, a recent study in a northern grassland with circumneutral $\mathrm{pH}$ found a large decrease in Ca-bound $\mathrm{C} v \mathrm{v}$. a slight increase in Fe-bound $\mathrm{C}$ following soil acidification (Ye et al. 2018). However, the impacts of additional soil acidification on organo-mineral interactions in highly weathered soils that are naturally acidic have not yet been addressed (Kuzyakov et al. 2021).

In China, about $40 \%$ of the total territory is affected by acid rain due to the continuing increase in anthropogenic activities (coal combustion, industrial emissions, and automobile exhaust) in recent decades. Particularly in southern China, acid deposition was currently estimated as $34.4 \mathrm{~kg} \mathrm{~N} \mathrm{ha}^{-1} \mathrm{yr}^{-1}$ and $32.6 \mathrm{~kg} \mathrm{~S} \mathrm{ha}^{-1} \mathrm{yr}^{-1}$ (Jiang et al. 2018), comparable with the highest levels of acid deposition in Europe and North America (Duan et al. 2016). High rates of acid deposition have increased public concern about its widespread impacts on the natural ecosystems in southern China (Liu et al. 2013). Forests in southern China account for approximately $34 \%$ of the forest area in China (Tang et al. 2018), and play an important role in global $\mathrm{C}$ balance (Yu et al. 2014). Soils in these forest ecosystems are acidic (often with $\mathrm{pH}<4.5$, and some even with $\mathrm{pH}<4$ ) and are highly weathered with a high content of reactive Fe phases (Zhang et al. 2010; Hu et al. 2015). Thus, Fe-bound C is likely to comprise an important portion of the total SOC stock in these forests (Coward et al. 2017). However, whether the mineral phases and organo-mineral associations in these highly acidic soils still respond significantly to further inputs of acid deposition has not been tested, which may have important implications for forest soil $\mathrm{C}$ sequestration in southern China and in other global regions with naturally acidic soils.

We carried out a long-term (nearly $10 \mathrm{yrs}$ ) field experiment with a gradient of acidity treatments $(0,9.6,32$, $96 \mathrm{~mol} \mathrm{H}^{+} \mathrm{ha}^{-1} \mathrm{yr}^{-1}$ as nitric acid + sulfuric acid) to examine acidification impacts on organo-mineral interactions and SOC pools (divided light and heavy fractions) in a tropical forest in southern China. Earlier work at this study site demonstrated that the acidity treatments significantly increased SOC stock and altered its biochemical composition (Wu et al. 2016). In this study we hypothesized that the acidity treatments enhanced SOC sequestration mainly arising from increased $\mathrm{C}$ in heavy (mineral-associated) fraction. We also expected that $\mathrm{pH}$-sensitive organo-mineral interactions, especially changes in $\mathrm{Fe}$ phases, could explain the responses of SOC pools. Specifically, under the acidity treatments we quantified 
1) the shift of mineral-associated $C$ pools (Fe-bound $C$ vs. Ca-bound $C$ ) and its absolute contribution to the increase in total SOC stock, and 2) the extent of cation losses and changes in Fe phases.

\section{Materials And Methods}

\section{Site description}

This study was conducted in Dinghushan National Nature Reserve (1133 ha), located in the middle part of Guangdong Province in southern China $\left(112^{\circ} 30^{\prime}-112^{\circ} 33^{\prime} \mathrm{E}, 23^{\circ} 09^{\prime}-23^{\circ} 11^{\prime} \mathrm{N}\right)$. This area is characterized by a typical south subtropical monsoon climate. The mean annual temperature is $21^{\circ} \mathrm{C}$, with the maximum and minimum average monthly temperature of $28.0^{\circ} \mathrm{C}$ in July and $12.6^{\circ} \mathrm{C}$ in January, respectively. Annual average relative humidity is $82 \%$, and the mean annual rainfall is $1927 \mathrm{~mm}$. Acid rain is a threat in this area with high deposition rates of $34.4 \mathrm{~kg} \mathrm{~N} \mathrm{ha}^{-1} \mathrm{yr}^{-1}$ and $32.6 \mathrm{~kg} \mathrm{~S} \mathrm{ha}^{-1} \mathrm{yr}^{-1}$ in recent decades (Liu et al. 2007), which has significantly lowered the soil pH of some forests to < 4 (Jiang et al. 2018).

In the reserve, there are three types of forests of different successional stages: the broadleaf forest, mixed pine and broadleaf forest, and pine forest. In this study, the experimental site was set up in the broadleaf forest, the most mature forest with age $>400$ year. The forest is located $250-300 \mathrm{~m}$ above sea level and occupies approximately 600 ha. The dominant species were Castanopsis chinensis, Cryptocarya concinna, Cryptocarya chinensis, Machilus chinensis, and Schima superba (Yan et al. 2006). The bedrock is sandstone and shale belonging to the Devonian Period. Soil type is lateritic red earth (Yan et al. 2015) and is classified as an Oxisol according to the Keys to Soil Taxonomy (Soil Survey Staff 2014).

\section{Experimental treatments and design}

The acidity experiment was initiated in June 2009. Twelve plots were established and divided into four acidity treatments with three replicates each. Each treatment plot was measured $10 \times 10 \mathrm{~m}^{2}$ and was surrounded by a $3 \mathrm{~m}$ wide buffer strip. All plots and treatments were randomly arranged. The acidity treatments were irrigated with water of different pH values: $\mathrm{CK}$ (control, $\mathrm{pH} 4.5), \mathrm{T} 1$ (pH 4.0), T2 (pH 3.5), and T3 (pH 3.0). To reflect the real mole ratio of $\mathrm{S}: \mathrm{N}$ in the region, acidic solutions were prepared by adding a mixture of $\mathrm{H}_{2} \mathrm{SO}_{4}$ and $\mathrm{HNO}_{3}$ in a 1:1 mole ratio to the local lake water based on the local acid rain records (Du et al. 2015). The simulated acid rain was applied to each plot below the canopy using a gasoline engine powered sprayer and sprayed twice a month. The amount applied to each plot was $40 \mathrm{~L}$ per application, equal to $4 \mathrm{~mm}$ rainfall. The $\mathrm{H}^{+}$added in each plot was estimated as $0,9.6,32,96 \mathrm{~mol} \mathrm{H}^{+}$ $\mathrm{ha}^{-1} \mathrm{yr}^{-1}$ in the T1, T2, T3 and T4 treatments, respectively, which was equal to about $0,0.6,2.0$ and 6.0 times of that in the through-fall of the forest. More details on the experimental design and methods can be found in Wu et al (2016).

\section{Sample collection and soil properties measurements}


In September 2018, four cores (diameter $=5 \mathrm{~cm}$ ) were randomly collected from the topsoil $(0-10 \mathrm{~cm})$ and subsoil $(10-20 \mathrm{~cm})$ in each plot, and combined to yield one composite sample per depth and plot. The soil sample was passed through a $2 \mathrm{~mm}$ sieve to remove rocks and plant roots, and then divided into two parts (field-moist soil sample and air-dried soil sample) for subsequent analysis. Fine roots (diameter $\leq$ $2 \mathrm{~mm}$ ) were picked and thoroughly rinsed in deionized water and dried at $60^{\circ} \mathrm{C}$ to constant biomass.

Soil moisture was determined by drying the field-moist soil samples at $105^{\circ} \mathrm{C}$ for $24 \mathrm{~h}$. Soil pH values were measured using a glass electrode after shaking the samples for approximately $30 \mathrm{~min}$ in deionized water. The soil to water ratio was 1:2.5. Microbial biomass carbon (MBC) was measured using the chloroform fumigation extraction technique (Jenkinson 1987). The soil extractable dissolved organic carbon (DOC) was measured on the same samples used for the analysis of MBC and calculated as the $\mathrm{K}_{2} \mathrm{SO}_{4}$ - extractable $\mathrm{C}$ concentration. Total SOC was measured with the air-dried soil samples by using the $\mathrm{K}_{2} \mathrm{Cr}_{2} \mathrm{O}_{7}+\mathrm{H}_{2} \mathrm{SO}_{4}$ oxidation method (Schollenberger 1927). Total soil $\mathrm{N}$ was determined by semimicro + Kjeldahl (Menefee and Overman 1940; Bremner 1960). Total Ca, Al and Fe in soil were extracted with $\mathrm{HNO}_{3}-\mathrm{HF}-\mathrm{HClO}_{4}$ and measured using atomic absorption spectrophotometry with a graphite furnace. Soil exchangeable cations $\left(\mathrm{Ca}^{2+}, \mathrm{Al}^{3+}\right.$, and $\mathrm{Fe}^{3+}$ ) were extracted with $0.1 \mathrm{M} \mathrm{BaCl}_{2}$ (soil:solution ratio of 1:50) and measured on an Agilent 5100 ICP-OES (Galí Navarro et al. 2011).

\section{Density fractionations}

Each field-moist soil sample (30 g dry mass equivalent) was separated into two operationally defined soil fractions, a light fraction (LF) and a heavy fraction (HF), following a modified density fractionation technique (Ye et al. 2018). Given that the soils used in this study were rich in clay, the LF was separated by flotation after immersing soils in Nal solution at a density of $1.85 \mathrm{~g} \mathrm{~cm}^{-3}$ combined with a ultrasonic treatment (a total energy input of $200 \mathrm{~J} \mathrm{~mL}^{-1}$ ) in order to disrupt soil aggregates. The residual soil consisted of the remaining mineral-associated organic matter (HF). The separated soil fractions were then dried in an oven at $60^{\circ} \mathrm{C}$ and ground to a homogenized fine powder for SOC analysis (interpreted as LF-C and HF-C).

\section{Determination of Ca-bound C and Fe-bound C}

The HF soil samples were sequentially extracted with $0.5 \mathrm{M} \mathrm{Na}_{2} \mathrm{SO}_{4}$ and the $\mathrm{C}$ released in the solutions was interpreted as organic $C$ associated with Ca bridges (Xu and Yuan 1993). The difference between HF$\mathrm{C}$ and the $\mathrm{C}$ concentrations of the residual soils after $\mathrm{Na}_{2} \mathrm{SO}_{4}$ extraction was calculated as Ca-bound $\mathrm{C}$. Next, Fe-bound organic $C$ was measured following a procedure adapted from Lalonde et al (2012). The residual soil after $\mathrm{Na}_{2} \mathrm{SO}_{4}$ extraction was added to a solution containing sodium bicarbonate and trisodium citrate in a $50 \mathrm{~mL}$ polycarbonate centrifuge tube and heated to $80^{\circ} \mathrm{C}$ in a water bath, and then sodium dithionite was added to the tube and maintained at $80^{\circ} \mathrm{C}$ for $15 \mathrm{~min}$. After centrifugation at 3000 $\mathrm{g}$ for $10 \mathrm{~min}$, the supernatant was separated from the solid fraction. The procedure was repeated three times and the residual soil was rinsed three times with deionized water and then oven dried at $80^{\circ} \mathrm{C}$ for 
organic $\mathrm{C}$ analysis, respectively. The concentrations of organic $\mathrm{C}$ in soil after dithionite-citrate-bicarbonate (DCB) extraction were subtracted from the $\mathrm{Na}_{2} \mathrm{SO}_{4}$-extracted samples to obtain Fe-associated organic $\mathrm{C}$.

\section{Determination of Fe phases}

During the determination of Fe-bound $\mathrm{C}$, the extracted solution was also analyzed by ICP-OES to measure the total free $\mathrm{Fe}$ (oxyhydr)oxides $\left(\mathrm{Fe}_{\mathrm{d}}\right)$. Dry HF subsamples were separately extracted with acid ammonium oxalate or sodium pyrophosphate to measure poorly crystalline (i.e., short-range-ordered, $\mathrm{SRO}) \mathrm{Fe}\left(\mathrm{Fe}_{\mathrm{o}}\right)$ and organically complexed and colloidal $\mathrm{Fe}\left(\mathrm{Fe}_{\mathrm{p}}\right)$, respectively. Briefly, soils were extracted in the dark using $0.175 \mathrm{M}$ ammonium oxalate and $0.1 \mathrm{M}$ oxalic acid at $\mathrm{pH}=3$ with a soil:solution ratio of 1:60 and shaken for $2 \mathrm{~h}$. Soils were extracted by $0.1 \mathrm{M}$ sodium pyrophosphate (soil:solution ratio of 1:20) at $\mathrm{pH}=10$ and the supernatant was syringe-filtered through a $0.2 \mu$ m nylon membrane filter after centrifugation at $2000 \mathrm{~g}$ for $15 \mathrm{~min}$. The Fe concentrations were determined by ICP-OES.

Additionally, the field-moist soil samples were extracted in $0.5 \mathrm{M}$ hydrochloric acid $(\mathrm{HCl})$ to measure $\mathrm{Fe}(\mathrm{II})$ and $\mathrm{Fe}(\mathrm{III})$ in $\mathrm{HCl}$, denoted $\mathrm{Fe}(\mathrm{II})_{\mathrm{HCl}}$ and $\mathrm{Fe}(\mathrm{III})_{\mathrm{HCl}}$ (Huang and Hall 2017). Briefly, field-moist soil samples ( $3 \mathrm{~g}$ dry mass equivalent) were immersed in a 1:10 ratio with $\mathrm{HCl}$ in the field, and then vortexed, shaken for $1 \mathrm{hr}$, and filtered to $0.22 \mu \mathrm{m}$. Concentrations of $\mathrm{Fe}(\mathrm{II})_{\mathrm{HCl}}$ were measured using a colorimetric ferrozine assay and corrected for $\mathrm{Fe}(\mathrm{III})_{\mathrm{HCl}}$ interference (Viollier et al. 2000). Field-moist soil samples were also extracted in $0.2 \mathrm{M}$ sodium citrate/ $0.05 \mathrm{M}$ ascorbic acid solutions to measure the easily reducible $\mathrm{Fe}$ oxides $\left(\mathrm{Fe}_{\mathrm{ca}}\right)$ in short-range-order minerals and organic fractions using microplate-based ferrozine methods (Huang and Hall 2017). Briefly, field-moist soil samples (1.5 g dry mass equivalent) were added to freshly prepared citrate/ascorbic solution in a 1:30 ratio, vortexed, shaken in the dark for $16 \mathrm{~h}$, and centrifuged for $10 \mathrm{~min}$ at $10,000 \mathrm{~g} .40 \mu \mathrm{L}$ of extract was added to $40 \mu \mathrm{L}$ of $10 \%$ hydroxylamine hydrochloride and $200 \mu \mathrm{L}$ of color reagent $\left(1 \mathrm{~g} \mathrm{~L}^{-1}\right.$ Ferrozine in $600 \mathrm{mM}$ HEPES buffer at $\mathrm{pH}$ 8), the absorbance at $562 \mathrm{~nm}$ was then recorded at $1 \mathrm{~h}$. The supernatant solution was decanted to a clean HDPE bottle for dark storage at $4^{\circ} \mathrm{C}$ for analysis within two weeks of collection. The difference between $\mathrm{Fe}_{d}$ and $\mathrm{Fe}_{\mathrm{ca}}\left(\mathrm{Fe}_{\mathrm{d}-\mathrm{ca}}\right)$ was interpreted as crystalline $\mathrm{Fe}$ (oxyhydr)oxides.

\section{Statistical analyses}

Data analyses were conducted using SPSS 20.0 for Windows (IBM Corporation, Armonk, New York, USA) and $R$ version 4.0.2. Analysis of Variance (ANOVA) was used to determine the statistical significance $(a=$ 0.05) of the acidity treatment, soil layer and their interactive effects on bulk SOC and its fractions/pools as well as mineral elements ( $\mathrm{Ca}, \mathrm{Al}$ and Fe including Fe oxides). Tukey's multiple comparison test (HSD) was conducted if significant effects of acid addition or soil layer were found. Pairwise relationships between soil pH and biogeochemical variables, as well as biogeochemical variables and SOC fractions/pools were assessed using Pearson correlation coefficients.

A structural equation modelling (SEM) approach was also used to test a conceptual model for the acid deposition impacts on LF-C and HF-C. The SEM analysis was performed with the IBM SPSS Amos 22.0 
using the maximum likelihood estimation method. Several tests were used to assess model fit: the Chisquare $\left(\mathrm{X}^{2}\right)$-test, comparative fit index $(\mathrm{CFI})$ and root square mean error of approximation (RMSEM).

\section{Results}

\section{Soil general characteristics}

Soil $\mathrm{pH}$ values decreased significantly under the acidity treatments compared to the control $(p<0.05$, Table 1), and pH was significantly lower in topsoil than in subsoil $(p<0.05$, Table 1$)$. There was no significant difference in soil moisture or bulk density among treatments $(p>0.05$ for both, Table 1$)$. The MBC in both topsoil and subsoil decreased significantly with the acidity treatments compared to the control ( $p<0.05$, Table 1), except for the subsoil in the T1 treatment $(p>0.05$, Table 1$)$. DOC in topsoil was significantly higher under the T1 and T3 treatment compared to control ( $p<0.05$, Table 1$)$, while in subsoil, DOC was significantly lower under the T3 than that under the T1 and T2 treatments $(p<0.05$, Table 1). The fine root biomass significantly decreased under the acidity treatments compared to the control $(p<0.05$, Table 1$)$, except for the T2 treatment $(p>0.05$, Table 1$)$. 
Table 1

Changes of soil properties, microbial biomass $\mathrm{C}$, dissolved organic $\mathrm{C}$ and fine root biomass under the acidity treatments. Values are means (SE).

\begin{tabular}{|c|c|c|c|c|c|}
\hline Property & $\begin{array}{l}\text { Depth } \\
\text { (cm) }\end{array}$ & CK & T1 & $\mathrm{T} 2$ & T3 \\
\hline \multirow[t]{2}{*}{ Soil pH } & $0-10$ & 3.95 (0.04)a & $3.76(0.04) b$ & $3.78(0.02) b$ & $\begin{array}{l}3.76 \\
(0.04) b\end{array}$ \\
\hline & $10-20$ & $4.04(0.02) a$ & $3.94(0.04) b$ & $\begin{array}{l}3.86 \\
(0.02) b c\end{array}$ & $\begin{array}{l}3.82 \\
(0.03) c\end{array}$ \\
\hline \multirow[t]{2}{*}{ Soil moisture (\%weight) } & $0-10$ & $0.34(0.01)$ & $0.36(0.01)$ & $0.35(0.01)$ & $0.33(0.01)$ \\
\hline & $10-20$ & $0.35(0.01)$ & $0.32(0.01)$ & $0.32(0.02)$ & $0.34(0.01)$ \\
\hline \multirow{2}{*}{$\begin{array}{l}\text { Soil bulk density }\left(\mathrm{g} \mathrm{cm}^{-}\right. \\
\left.{ }^{-}\right)\end{array}$} & $0-10$ & $1.24(0.08)$ & $1.25(0.06)$ & $1.28(0.11)$ & $1.23(0.09)$ \\
\hline & $10-20$ & $1.16(0.06)$ & $1.13(0.08)$ & $1.16(0.05)$ & $1.15(0.09)$ \\
\hline \multirow[t]{2}{*}{$\operatorname{MBC}\left(\mathrm{g} \mathrm{kg}^{-1}\right)$} & $0-10$ & $0.55(0.02) a$ & $0.48(0.01) \mathrm{b}$ & $0.37(0.02) c$ & $\begin{array}{l}0.36 \\
(0.02) c\end{array}$ \\
\hline & $10-20$ & $0.42(0.02) a$ & $\begin{array}{l}0.40 \\
(0.03) a b\end{array}$ & $\begin{array}{l}0.35 \\
(0.03) b c\end{array}$ & $\begin{array}{l}0.32 \\
(0.02) c\end{array}$ \\
\hline \multirow[t]{2}{*}{$\mathrm{DOC}\left(\mathrm{g} \mathrm{kg}^{-1}\right)$} & $0-10$ & $0.30(0.01) \mathrm{b}$ & $0.36(0.00) a$ & $0.32(0.02) b$ & $\begin{array}{l}0.38 \\
(0.01) a\end{array}$ \\
\hline & $10-20$ & $\begin{array}{l}0.25 \\
(0.01) \mathrm{ab}\end{array}$ & $0.26(0.03) a$ & $0.23(0.01) \mathrm{b}$ & $\begin{array}{l}0.23 \\
(0.02) b\end{array}$ \\
\hline $\begin{array}{l}\text { Fine root biomass }(\mathrm{kg} \\
\mathrm{m}^{-2} \text { ) }\end{array}$ & $0-20$ & $0.28(0.01) a$ & $0.24(0.01) b$ & $\begin{array}{l}0.25 \\
(0.02) a b\end{array}$ & $\begin{array}{l}0.17 \\
(0.01) c\end{array}$ \\
\hline \multicolumn{6}{|c|}{$\begin{array}{l}\text { The acidity treatments are: } \mathrm{CK}=\text { control }\left(0 \mathrm{~mol} \mathrm{H}^{+} \mathrm{ha}^{-1} \mathrm{yr}^{-1}\right), \mathrm{T} 1=9.6 \mathrm{~mol} \mathrm{H}^{+} \mathrm{ha}^{-1} \mathrm{yr}^{-1}, \mathrm{~T} 2=32 \mathrm{~mol} \\
\mathrm{H}^{+} \mathrm{ha}^{-1} \mathrm{yr}^{-1} \text {, and T3 }=96 \mathrm{~mol} \mathrm{H}^{+} \mathrm{ha}^{-1} \mathrm{yr}^{-1} \text {. Different letters in each soil layer denote significant } \\
\text { difference }(p<0.05) \text { among the treatments. MBC, microbial biomass carbon; DOC, dissolved organic } \\
\text { carbon. }\end{array}$} \\
\hline
\end{tabular}

\section{Soil geochemical characteristics}

Total $\mathrm{Ca}$ and Fe contents in both topsoil and subsoil and total Al content only in subsoil decreased significantly under the acidity treatments compared to the control ( $p<0.05$ for all, Table 2$)$. The exchangeable $\mathrm{Ca}^{2+}$ in topsoil was significantly lower in $\mathrm{T} 1$ than in T3 treatment $(p<0.05$, Table 2), but neither significantly differed from the control ( $p>0.05$, Table 2 ). In subsoil, exchangeable $\mathrm{Ca}^{2+}$ in the control was significantly higher than in the T1 and T2 treatments $(p<0.05$, Table 2$)$, but not in the T3 treatment $(p>0.05$, Table 2$)$. Exchangeable $\mathrm{Al}^{3+}$ and $\mathrm{Fe}^{3+}$ in both topsoil and subsoil increased significantly with the acidity treatments compared to the control $(p<0.05$ for both, Table 2$)$. 
Table 2

Changes of the total and extractable $\mathrm{Ca}, \mathrm{Al}, \mathrm{Fe}$ under the acidity treatments. Values are means (SE).

\begin{tabular}{|c|c|c|c|c|c|}
\hline Property & $\begin{array}{l}\text { Depth } \\
\text { (cm) }\end{array}$ & CK & $\mathrm{T} 1$ & T2 & T3 \\
\hline \multirow[t]{2}{*}{ Total $\mathrm{Ca}\left(\mathrm{g} \mathrm{kg}^{-1}\right)$} & $0-10$ & $0.58(0.10) a$ & $0.36(0.06) b$ & $0.25(0.04) b$ & $0.22(0.04) b$ \\
\hline & $10-20$ & $0.56(0.08) a$ & $0.23(0.06) b$ & $0.20(0.02) b$ & $0.09(0.02) b$ \\
\hline \multirow[t]{2}{*}{ Total Al $\left(\mathrm{g} \mathrm{kg}^{-1}\right)$} & $0-10$ & $\begin{array}{l}77.54 \\
(1.64) a b\end{array}$ & $\begin{array}{l}79.86 \\
(1.45) a\end{array}$ & $\begin{array}{l}73.44 \\
(1.97) \mathrm{b}\end{array}$ & $\begin{array}{l}78.84 \\
(2.87) a b\end{array}$ \\
\hline & $10-20$ & $\begin{array}{l}89.60 \\
(2.28) a\end{array}$ & $\begin{array}{l}83.13 \\
(2.26) \mathrm{b}\end{array}$ & $\begin{array}{l}77.64 \\
(1.22) \mathrm{b}\end{array}$ & $\begin{array}{l}77.73 \\
(2.24) b\end{array}$ \\
\hline \multirow[t]{2}{*}{ Total Fe $\left(\mathrm{g} \mathrm{kg}^{-1}\right)$} & $0-10$ & $\begin{array}{l}42.23 \\
(0.49) a\end{array}$ & $\begin{array}{l}40.74 \\
(0.54) b\end{array}$ & $\begin{array}{l}37.94 \\
(0.33) c\end{array}$ & $\begin{array}{l}39.90 \\
(0.39) b c\end{array}$ \\
\hline & $10-20$ & $\begin{array}{l}43.38 \\
(0.70) a\end{array}$ & $\begin{array}{l}41.03 \\
(0.44) b\end{array}$ & $\begin{array}{l}40.68 \\
(0.36) \mathrm{b}\end{array}$ & $\begin{array}{l}39.32 \\
(0.66) b\end{array}$ \\
\hline \multirow[t]{2}{*}{$\begin{array}{l}\text { Exchangeable } \mathrm{Ca}^{2+}(\mathrm{g} \\
\left.\mathrm{kg}^{-1}\right)\end{array}$} & $0-10$ & $\begin{array}{l}0.11 \\
(0.01) a b\end{array}$ & $0.08(0.01) b$ & $\begin{array}{l}0.10 \\
(0.01) a b\end{array}$ & $0.12(0.01) a$ \\
\hline & $10-20$ & $0.07(0.01) a$ & $0.02(0.00) c$ & $0.06(0.00) b$ & $0.09(0.01) a$ \\
\hline \multirow{2}{*}{$\begin{array}{l}\text { Exchangeable } \mathrm{Al}^{3+}(\mathrm{g} \\
\left.\mathrm{kg}^{-1}\right)\end{array}$} & $0-10$ & $0.67(0.02) \mathrm{b}$ & $0.93(0.05) a$ & $0.88(0.02) a$ & 0.88 (0.03)a \\
\hline & $10-20$ & $0.60(0.02) \mathrm{c}$ & $0.71(0.05) b$ & $\begin{array}{l}0.73 \\
(0.03) a b\end{array}$ & $0.82(0.03) a$ \\
\hline \multirow{2}{*}{$\begin{array}{l}\text { Exchangeable } \mathrm{Fe}^{3+}(\mathrm{mg} \\
\left.\mathrm{kg}^{-1}\right)\end{array}$} & $0-10$ & $16.91(0.66) c$ & $36.87(1.00) b$ & $34.02(3.80) b$ & $42.50(2.73) \mathrm{a}$ \\
\hline & $10-20$ & $14.81(1.22) \mathrm{c}$ & $21.53(1.41) b$ & $27.39(2.61) a$ & $20.60(2.35) b$ \\
\hline \multicolumn{6}{|c|}{$\begin{array}{l}\text { The acidity treatments are: } \mathrm{CK}=\text { control }\left(0 \mathrm{~mol} \mathrm{H}^{+} \mathrm{ha}^{-1} \mathrm{yr}^{-1}\right), \mathrm{T} 1=9.6 \mathrm{~mol} \mathrm{H}^{+} \mathrm{ha}^{-1} \mathrm{yr}^{-1}, \mathrm{~T} 2=32 \mathrm{~mol} \\
\mathrm{H}^{+} \mathrm{ha}^{-1} \mathrm{yr}^{-1} \text {, and T3 }=96 \mathrm{~mol} \mathrm{H}^{+} \mathrm{ha}^{-1} \mathrm{yr}^{-1} \text {. Different letters in each soil layer denote significant } \\
\text { differences }(p<0.05) \text { among the treatments. }\end{array}$} \\
\hline
\end{tabular}

\section{Soil iron phases}

The concentrations of $\mathrm{Fe}(\mathrm{II})_{\mathrm{HCl}}, \mathrm{Fe}(\mathrm{III})_{\mathrm{HCl}}$, and $\mathrm{Fe}_{\mathrm{Ca}}$ in both topsoil and subsoil increased significantly under the acidity treatments compared to the control ( $p<0.05$ for all, Table 3 ). Soil Fe $e_{d}$ concentrations did not vary consistently among treatments and between soil layers (Table 3). However, the concentrations of $\mathrm{Fe}_{\mathrm{d}-\mathrm{ca}}$ in both topsoil and subsoil decreased significantly under the acidity treatments compared to the control ( $p<0.05$ for both, Table 3 ). Soil Fe $\mathrm{p}_{\mathrm{p}}$ concentrations in both topsoil and subsoil also decreased significantly with the acidity treatments $(p<0.05$, Table. 3$)$, while $\mathrm{Fe}_{\mathrm{o}}$ concentrations were not significantly influenced by the acidity treatments $(p>0.05$, Table 3$)$. 
Table 3

Changes of Fe phases under the acidity treatments. Values are means (SE).

\begin{tabular}{|c|c|c|c|c|c|}
\hline Fe pool & Depth (cm) & CK & T1 & T2 & T3 \\
\hline \multirow[t]{2}{*}{$\mathrm{Fe}(\mathrm{II})_{\mathrm{HCl}}\left(\mathrm{g} \mathrm{kg}^{-1}\right)$} & $0-10$ & $0.19(0.01) c$ & $0.29(0.01) a$ & $0.22(0.02) b$ & $0.24(0.01) a b$ \\
\hline & $10-20$ & $0.18(0.01) b$ & 0.20 (0.01)ab & 0.19 (0.01)ab & $0.21(0.01) a$ \\
\hline \multirow[t]{2}{*}{$\mathrm{Fe}(\mathrm{III})_{\mathrm{HCl}}\left(\mathrm{g} \mathrm{kg}^{-1}\right)$} & $0-10$ & $1.52(0.02) \mathrm{c}$ & $2.32(0.08) a$ & $2.05(0.18) b$ & $2.05(0.12) b$ \\
\hline & $10-20$ & $1.67(0.05) b$ & $1.86(0.06) a$ & 1.69 (0.09)ab & $1.90(0.04) a$ \\
\hline \multirow[t]{2}{*}{$\mathrm{Fe}_{\mathrm{ca}}\left(\mathrm{g} \mathrm{kg}^{-1}\right)$} & $0-10$ & $3.93(0.17) c$ & $4.62(0.13) b$ & $4.46(0.04) b$ & $4.91(0.07) a$ \\
\hline & $10-20$ & $3.49(0.14) c$ & $4.16(0.05) b$ & $4.99(0.10) a$ & $4.21(0.04) b$ \\
\hline \multirow[t]{2}{*}{$\mathrm{Fe}_{\mathrm{d}}\left(\mathrm{g} \mathrm{kg}^{-1}\right)$} & $0-10$ & $13.38(0.18) b$ & $14.05(0.27) a$ & $13.61(0.53) a b$ & $14.16(0.26) a$ \\
\hline & $10-20$ & $14.54(0.29) a$ & 13.86(0.52)ab & $14.78(0.24) a$ & $13.69(0.30) b$ \\
\hline \multirow[t]{2}{*}{$\mathrm{Fe}_{\mathrm{d}-\mathrm{ca}}\left(\mathrm{g} \mathrm{kg}^{-1}\right)$} & $0-10$ & $9.46(0.12) a$ & $9.41(0.06) a b$ & $9.14(0.53) a b$ & $9.24(0.03) b$ \\
\hline & $10-20$ & $11.05(0.05) a$ & $9.39(0.12) \mathrm{c}$ & $9.79(0.11) b$ & $9.48(0.34) c$ \\
\hline \multirow[t]{2}{*}{$\mathrm{Fe}_{\mathrm{p}}\left(\mathrm{g} \mathrm{kg}^{-1}\right)$} & $0-10$ & $9.84(0.11) a$ & $8.89(0.20) b$ & $8.49(0.20) b$ & $8.15(0.35) b$ \\
\hline & $10-20$ & $10.24(0.22) a$ & $8.25(0.32) b$ & $9.01(0.20) \mathrm{b}$ & $8.49(0.31) b$ \\
\hline \multirow[t]{2}{*}{$\mathrm{Fe}_{\mathrm{o}}\left(\mathrm{g} \mathrm{kg}^{-1}\right)$} & $0-10$ & $3.45(0.11)$ & $3.63(0.13)$ & $3.58(0.10)$ & $3.53(0.24)$ \\
\hline & $10-20$ & $3.94(0.08)$ & $3.99(0.04)$ & $4.00(0.15)$ & $3.88(0.09)$ \\
\hline \multicolumn{6}{|c|}{ 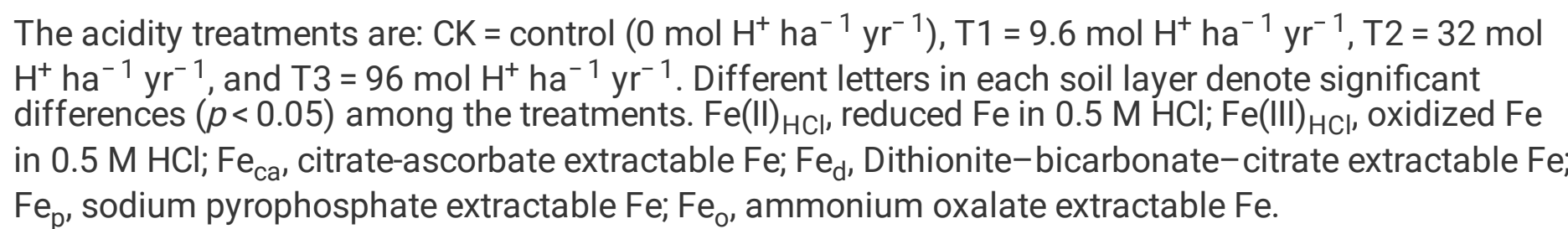 } \\
\hline
\end{tabular}

\section{Soil organic carbon fractions}

The total SOC content increased significantly under the acidity treatments compared to the control, except for the T1 treatment in both topsoil and subsoil ( $p<0.05$, Fig. 1a). Both LF-C and HF-C concentration and stock also increased significantly under the acidity treatments compared to the control, except for the HF-C in the T1 treatment in subsoil $(p<0.05$, Fig. $1 \mathrm{~b}, \mathrm{c})$. Since the bulk density did not change among treatments ( $p>0.05$, Table 1$)$, the stock of SOC and its fractions varied similarly with their content (Fig. 1). Overall, the acidity treatments increased LF-C to $3.1-4.1 \mathrm{Mg} \mathrm{C}^{-1}$ vs. $1.6 \mathrm{Mg} \mathrm{Cha}^{-1}$ in the control and increased HF-C to $32.5-36.4 \mathrm{Mg} \mathrm{Cha}^{-1}$ vs. $28.8 \mathrm{Mg} \mathrm{Cha}^{-1}$ in the control. The increase in LF-C and HF-C accounted for $22-32 \%$ and $78-83 \%$, respectively, in the increase of the total SOC stock. 
The content of Ca-bound $\mathrm{C}$ in the topsoil showed no significant change among treatments $(p>0.05$, Fig. 1d), while in the subsoil it decreased significantly under acidity treatments compared to the control $(p<0.05$, Fig. 1d). Fe-bound $\mathrm{C}$ in both topsoil and subsoil increased significantly with the acidity treatments compared to the control $(p<0.05$, Fig. 1e).

Relationships among the SOC fractions and geochemical characteristics

Across all treatments, soil pH was negatively correlated with SOC, LF-C, HF-C and Fe-bound C, but not with Ca-bound C (Fig. 2a). SOC was positively correlated with both LF-C and HF-C (Fig. 2b,c). HF-C was positively correlated with Fe-bound C only, but not with Ca-bound C (Fig. 2d,e).

Soil pH was also negatively correlated with exchangeable $\mathrm{Al}^{3+}$, exchangeable $\mathrm{Fe}^{3+}, \mathrm{Fe}(\mathrm{II})_{\mathrm{HCl}}, \mathrm{Fe}(\mathrm{III})_{\mathrm{HCl}}$, and $\mathrm{Fe}_{\mathrm{ca}}$, while total $\mathrm{Ca}$, total $\mathrm{Fe}$, total $\mathrm{Al}$, and $\mathrm{Fe}_{\mathrm{p}}$ showed opposite relationships (Fig. 3a). The Ca-bound $\mathrm{C}$ was positively correlated with the loss of total $\mathrm{Ca}$ only, but not with exchangeable $\mathrm{Ca}^{2+}$ (Fig. 3b). However, the Fe-bound $\mathrm{C}$ was positively correlated with exchangeable $\mathrm{Fe}^{3+}$ and $\mathrm{Al}^{3+}$ (Fig. 3c,d). The Fe-bound $\mathrm{C}$ was also positively correlated with the concentrations of $\mathrm{Fe}(\mathrm{II})_{\mathrm{HCl}}, \mathrm{Fe}(\mathrm{III})_{\mathrm{HCl}}$, and $\mathrm{Fe}_{\mathrm{ca}}(\mathrm{Fig} .3 e, \mathrm{f}, \mathrm{g})$.

\section{Controls on SOC and fraction changes under the acidity treatments}

The SEM model implied by our data showed that the decreased soil pH under the acidity treatments was the optimal predictor and directly explained $53 \%, 63 \%$ and $83 \%$ of the variance in fine root biomass, Febound C, and LF-C, respectively (Fig. 4). There was no significant relationship of soil pH with MBC or Cabound $\mathrm{C}$. Fine root biomass had a direct negative relationship with $\mathrm{MBC}\left(R^{2}=0.46\right)$, whereas neither fine root biomass nor MBC was significantly related to LF-C. Change in LF-C directly explained $50 \%$ of the variance in DOC, which in turn together with Fe-bound $\mathrm{C}$ directly explained $81 \%$ of the variance in HF-C. There was no significant relationship of HF-C with MBC and Ca-bound C, respectively.

\section{Discussion}

We found that the acidity treatments significantly increased total SOC content and stock including both light and heavy fractions (Fig. 1a, b, c). The increased SOC was unlikely to have come from greater plant C input, as soil acidification was previously shown to limit plant productivity and led to decreased fine root biomass as reported in this study (Liang et al. 2013; Table 1). The acidity treatments also decreased MBC (Table 1) and could inhibit soil respiration (Wu et al. 2016), which might also have contributed to the observed SOC accumulation. However, decreased MBC might be expected to cause higher LF-C but lower $\mathrm{HF}-\mathrm{C}$, because microbial residues derived from catabolism of LF-C can potentially be important constituents contributing to mineral-associated C (Cotrufo et al. 2013; Liang et al. 2017). In contrast to this reasoning, we found that the HF-C increased much more in absolute amount than the LF-C under the acidity treatments. Consistent with our hypothesis, the acidity treatments increased the HF-C stock, which accounted for most of the total increase in SOC stock (Table 4). 
With a SEM model implied by our data, we further found that $\mathrm{pH}$-sensitive organo-mineral interactions particulatly changes in Fe phases, to a large extent, explained the increase of HF-C under the acidity treatments. The increase in Fe-bound $\mathrm{C}$ under the acidity treatments was much larger than the decrease in Ca-bound C (Fig. 1d, e). Consistent with pH buffering by dissolution of $\mathrm{Al}$ and Fe phases in acidic soils, we found that the acidity treatment generally decreased exchangeable $\mathrm{Ca}^{2+}$, while soil extractable $\mathrm{Al}^{3+}$ and $\mathrm{Fe}^{3+}$ increased significantly (Table 2). In an alpine grassland of Europe with soil $\mathrm{pH}<3.5$, acid deposition similarly led to buffering by $\mathrm{Al}^{3+}$ and $\mathrm{Fe}^{3+}$ (Bowman et al. 2008). Increases of extractable $\mathrm{Al}^{3+}$ and $\mathrm{Fe}^{3+}$ under the acidity treatments reflect the enhanced solubility of $\mathrm{Al}$ and Fe mineral phases (Gu et al. 1994; Mueller et al. 2012), causing losses of these metals via leaching as indicated by decreases in total $\mathrm{Al}$ and $\mathrm{Fe}$ in the subsoil (Table 2). However, increased $\mathrm{Al}$ and Fe solubility likely also promoted formation of new organic-mineral complexes between DOC and Fe/Al phases, perhaps through ligand exchange between carboxyl groups of organic matter and singly coordinated inorganic hydroxyl groups at metal/mineral surfaces (Masiello et al. 2004; Chen et al. 2014). Negative relationships between DOC leaching and extractable $\mathrm{Al}^{3+}$ or $\mathrm{Fe}^{3+}$ with increasing soil acidity have frequently been observed in acid soils (Kalbitz et al. 2000; Filep and Rékási 2011; Lu et al. 2013; Xiao et al. 2013). Previous work at our study site also found that the acidity treatments significantly decreased the DOC leaching flux (Qiu et al. 2013 , 2015), and here we found positive relationships between soil exchangeable $\mathrm{Al}^{3+}$ and $\mathrm{Fe}^{3+}$ with mineral-associated C, consistent with DOC sorption or co-precipitation (Fig. 3). In addition, soil acidification could decrease the solubility of organic matter due to the protonation of organic acid functional groups at $\mathrm{pH}$ values approaching zero net charge (Chorover and Sposito 1995), as well as by increasing molecular aggregation (Louzao et al. 1990).

Changes in Fe phase compositions under the acidity treatments were also likely related to the large increase in Fe-bound $\mathrm{C}$ pool in this study (Fig. 4b). We found that the acidity treatments significantly decreased $\mathrm{Fe}_{\mathrm{d}-\mathrm{ca}}$ while $\mathrm{Fe}(\mathrm{II})_{\mathrm{HCl}}, \mathrm{Fe}(\mathrm{III})_{\mathrm{HCl}}$ and $\mathrm{Fe}_{\mathrm{ca}}$ increased (Table 3). These contrasting changes in Fe pools likely reflect the progressive transformation of crystalline Fe oxides into increasingly short-rangeordered Fe phases. Decreased $\mathrm{Fe}_{\mathrm{d}-\mathrm{ca}}$ indicates that soil acidification increased the solubility of crystalline Fe oxides, as observed in other acid forest soils (Guo et al. 2007). Intriguingly, we also found that $\mathrm{Fe}_{\mathrm{p}}$ decreased under the acidity treatments, possibly indicating competition between $\mathrm{H}^{+}$and $\mathrm{Fe}^{3+}$ for binding sites in soil organic matter under these highly acidic conditions, leading to release of $\mathrm{Fe}^{3+}$ from monomeric organo-Fe complexes and its subsequent precipitation in Fe phases that were not extracted by $\mathrm{Fe}_{\mathrm{p}}$. The formation of new short-range-ordered Fe phases was consistent with the observed increase in the $\mathrm{Fe}_{\mathrm{Ca}}$ and $\mathrm{Fe}(\mathrm{III})_{\mathrm{HCl}}$ pools, which include highly reactive portions of soil Fe (Hall and Silver 2015). The fact that $\mathrm{Fe}(\mathrm{II})_{\mathrm{HCl}}$ was a small portion of the $0.5 \mathrm{M} \mathrm{HCl}$-extractable Fe pool indicated that acid-mediated dissolution, rather than reductive dissolution, was likely the dominant process controlling the observed changes in soil Fe (Table 3). Finally, the new Fe phases in the acidity treatments likely associated with DOC inputs via adsorption and co-precipitation (Wagai and Mayer 2007; Chen et al. 2014; Mikutta et al. 2014; Coward et al. 2017), as evidenced by the positive relationships of soil $\mathrm{Fe}(\mathrm{III})$ and $\mathrm{Fe}_{\mathrm{ca}}$ with Fe-bound $\mathrm{C}$ under the acidity treatments (Fig. 3d,e,f). 
Our results have also important implications for understanding the impacts on SOC sequestration of ongoing acidification from atmospheric $\mathrm{N}$ deposition in tropical forests. At the global scale, soil pH decreases linearly with $\mathrm{N}$ addition (Tian and Niu 2015), and at our study site, a parallel experiment with $\mathrm{N}$ addition alone also revealed significant soil acidification (Lu et al. 2014). N-induced increases in SOC have been detected from temperate to tropical forests, but the underlying mechanisms in tropical forests remain poorly understood (Lu et al. 2021). Because many tropical forests are more strongly limited by phosphorus $(\mathrm{P})$ than $\mathrm{N}$, increased plant productivity and $\mathrm{C}$ input of plant residue cannot likely explain increases in SOC (Lu et al. 2021). N-induced soil acidification is widely known to suppress certain aspects of microbial decomposition activity, such as production of oxidative enzymes (Chen et al. 2018), and these changes have previously been invoked to explain the increased SOC stock and the change of biochemical composition under $\mathrm{N}$ addition (Cusack et al. 2011). Rather, a recent study by Lu et al (2021) showed that in tropical forests $\mathrm{N}$ addition increased SOC sequestration, mainly arising from increased $\mathrm{C}$ in heavy (mineral-associated) fraction accompanied by acidification-induced the decreases in both soil $\mathrm{CO}_{2}$ efflux and DOC leaching. Here our data suggest that $\mathrm{pH}$-sensitive organo-mineral interactions, especially formation of new Fe-C associations that provide protection from SOC decomposition and DOC leaching, play a key role in regulating the response of SOC pools in tropical forests and explain the observed increases in mineral-associated C.

\section{Conclusions}

Using a long-term acidity manipulation field experiment, we found that increased inputs of acid deposition in a highly weathered and naturally acidic tropical soil could enhance SOC sequestration, which mainly arising from increased $\mathrm{C}$ in mineral-associated fraction. Accordingly, soil organo-mineral interactions responded significantly to further inputs of acid deposition, with increased the leaching of base cations (e.g. $\mathrm{Ca}^{2+}$ ) and the solubility of $\mathrm{Al}$ and Fe phases. These acidity treatments converted more crystalline $\mathrm{Fe}$ (oxyhydr)oxides to short-range-ordered phases, resulting in a large increase in Fe-bound $\mathrm{C}$ $v s$. a relatively small decrease in Ca-bound $\mathrm{C}$. With a SEM model implied by our data, our results further highlight the importance of $\mathrm{pH}$-sensitive geochemical changes and the key roles of Fe in regulating the response of SOC to acid deposition in highly weathered soils. Therefore, accounting for $\mathrm{pH}$-sensitive geochemistry is critical to predict ecosystem $\mathrm{C}$ budgets under future acid deposition scenarios, and that these principles could be usefully incorporated in mechanistic biogeochemical models.

\section{Declarations}

\section{Acknowledgements}

The research was financially supported by the National Natural Science Foundation of China (31870461, 41773088, 41573077), the "Hundred Talent Program" of South China Botanical Garden at the Chinese Academy of Sciences (Y761031001), the "Young Top-notch Talent" in Pearl River talent plan of Guangdong Province (No. 2019QN01L763), and by the Key Special Project for Introduced Talents Team of Southern Marine Science and Engineering Guangdong Laboratory (Guangzhou) (GML2019ZD0408). 


\section{Author contributions}

QD and DZ planned the research; JC, YH, JL and LS conducted the field research; JC also conducted the laboratory research, analyzed results and wrote the original draft; SJH, QD and $\mathrm{DH}$ provided constructive comments and suggestions in the manuscript writing; and all authors edited the manuscript.

\section{Conflict of interest}

The authors declare that they have no known competing financial interests or personal relationships that could have appeared to influence the work reported in this paper.

\section{Data availability}

Data and materials are available upon request from the corresponding author.

\section{References}

1. Averill C, Waring B (2018) Nitrogen limitation of decomposition and decay: How can it occur? Glob Chang Biol 24:1417-1427. https://doi.org/10.1111/gcb.13980

2. Bowman WD, Cleveland CC, Halada L, et al (2008) Negative impact of nitrogen deposition on soil buffering capacity. Nat Geosci 1:767-770. https://doi.org/10.1038/ngeo339

3. Bremner JM (1960) Determination of nitrogen in soil by the Kjeldahl method. J Agr Sci-Cambridge 55: 11-33. https://doi.org/10.1017/S0021859600021572

4. Chadwick OA, Chorover J (2001) The chemistry of pedogenic thresholds. Geoderma 100: 321-353. https://doi.org/10.1016/S0016-7061(01)00027-1

5. Chen C, Dynes JJ, Wang J, Sparks DL (2014) Properties of Fe-organic matter associations via coprecipitation versus adsorption. Environ Sci $\backslash \&$ Technol 48:13751-13759. https://doi.org/10.1021/es503669u

6. Chen J, Luo Y, van Groenigen KJ, et al (2018) A keystone microbial enzyme for nitrogen control of soil carbon storage. Sci Adv 4. https://doi.org/10.1126/sciadv.aaq1689

7. Chorover J, Sposito G (1995) Colloid chemistry of kaolinitic tropical soils. Soil Sci Soc Am J 59:1558-1564. https://doi.org/10.2136/sssaj1995.03615995005900060007x

8. Cotrufo MF, Wallenstein MD, Boot CM et al (2013) The Microbial Efficiency-Matrix Stabilization (MEMS) framework integrates plant litter decomposition with soil organic matter stabilization: do labile plant inputs form stable soil organic matter? Glob Chang Biol 19:988-995. https://doi.org/10.1111/gcb.12113

9. Coward EK, Thompson AT, Plante AF (2017) Iron-mediated mineralogical control of organic matter accumulation in tropical soils. Geoderma 306:206-216.

https://doi.org/10.1016/j.geoderma.2017.07.026 
10. Cusack DF, Silver WL, Torn MS, McDowell WH (2011) Effects of nitrogen additions on above- and belowground carbon dynamics in two tropical forests. Biogeochemistry 104:203-225. https://doi.org/10.1007/s10533-010-9496-4

11. Du E, de Vries W, Liu X, et al (2015) Spatial boundary of urban ‘acid islands' in southern China. Sci Rep 5. https://doi.org/10.1038/srep12625

12. Duan L, Yu Q, Zhang Q, et al (2016) Acid deposition in Asia: Emissions, deposition, and ecosystem effects. Atmos Environ 146:55-69. https://doi.org/10.1016/j.atmosenv.2016.07.018

13. Filep T, Rekasi M (2011) Factors controlling dissolved organic carbon (DOC), dissolved organic nitrogen (DON) and DOC/DON ratio in arable soils based on a dataset from Hungary. Geoderma 162:312-318. https://doi.org/10.1016/j.geoderma.2011.03.002

14. Gali Navarro EM, Villanueva Tagle ME, Larrea Marin MT, Pomares Alfonso MS (2011) Comparison of USEPA 3050B and ISO 14869-1:2001 digestion methods for sediment analysis by using FAAS and ICP-OES quantification techniques. Quim Nova 34:1443-1449. https://doi.org/10.1590/S010040422011000800025

15. Galloway JN, Townsend AR, Erisman JW, et al (2008) Transformation of the nitrogen cycle: Recent trends, questions, and potential solutions. Science 320:889-892. https://doi.org/10.1126/science. 1136674

16. Gu BH, Schmitt J, Chen ZH, et al (1994) Adsorption and desorption of natural organic-matter on ironoxide - mechanisms and models. Environ Sci $\backslash \&$ Technol 28:38-46. https://doi.org/10.1021/es00050a007

17. Guggenberger G, Kaiser K (2003) Dissolved organic matter in soil: challenging the paradigm of sorptive preservation. Geoderma 113:293-310. https://doi.org/10.1016/S0016-7061(02)00366-X

18. Guo X, Wu H, Luo M, et al (2007) The morphological change of Fe/Al-oxide minerals in red soils in the process of acidification and its environmental significance. Acta Petrologica et Mineralogica 26: 515-521. https://doi.org/1000-6524.2007.06.008

19. Hall SJ, Silver WL (2015) Reducing conditions, reactive metals, and their interactions can explain spatial patterns of surface soil carbon in a humid tropical forest. Biogeochemistry 125:149-165. https://doi.org/10.1007/s10533-015-0120-5

20. Hu B, Peng Y, Duan N, et al (2015) Study on the influence factors of accurate definition of the spatial distribution of acid rain area in China. China Environ. Sci. 35: 917-924. (in Chinese with English abstract)

21. Huang W, Hall SJ (2017) Optimized high-throughput methods for quantifying iron biogeochemical dynamics in soil. Geoderma 306:67-72. https://doi.org/10.1016/j.geoderma.2017.07.013

22. Jenkinson DS (1987) Determination of microbial biomass carbon and nitrogen in soil. In: Wilson, J.T. (Ed.), Advances in nitrogen cycling in agricultural ecosystems. CAB International, Wallingford, pp 368-386.

23. Jiang J, Wang Y-P, Yu M, et al (2018) Soil organic matter is important for acid buffering and reducing aluminum leaching from acidic forest soils. Chem Geol 501:86-94. 
https://doi.org/10.1016/j.chemgeo.2018.10.009

24. Johnson CE (2002) Cation exchange properties of acid forest soils of the northeastern USA. Eur J Soil Sci 53:271-282. https://doi.org/10.1046/j.1365-2389.2002.00441.x

25. Kaiser K, Guggenberger $G$ (2000) The role of DOM sorption to mineral surfaces in the preservation of organic matter in soils. Org Geochem 31:711-725. https://doi.org/10.1016/S0146-6380(00)00046-2

26. Kalbitz K, Solinger S, Park JH, et al (2000) Controls on the dynamics of dissolved organic matter in soils: A review. Soil Sci 165:277-304. https://doi.org/10.1097/00010694-200004000-00001

27. Kirk GJD, Bellamy PH, Lark RM (2010) Changes in soil pH across England and Wales in response to decreased acid deposition. Glob Chang Biol 16:3111-3119. https://doi.org/10.1111/j.13652486.2009.02135.x

28. Kuzyakov Y, Kuzyakova I, Raza S, et al (2021) Letter-to-the-Editor: Does acidification really increase soil carbon in croplands? How statistical analyses of large datasets might mislead the conclusions. Geoderma 384:114806. https://doi.org/https://doi.org/10.1016/j.geoderma.2020.114806

29. Lalonde K, Mucci A, Ouellet A, Gelinas Y (2012) Preservation of organic matter in sediments promoted by iron. Nature 483:198-200. https://doi.org/10.1038/nature10855

30. Li W, Johnson CE (2016) Relationships among pH, aluminum solubility and aluminum complexation with organic matter in acid forest soils of the Northeastern United States. Geoderma 271:234-242. https://doi.org/10.1016/j.geoderma.2016.02.030

31. Liang C, Schimel JP, Jastrow JD (2017) The importance of anabolism in microbial control over soil carbon storage. Nat Microbiol 2(8):17105. https://doi.org/10.1038/nmicrobiol.2017.105

32. Liang G, Liu X, Chen X, et al (2013) Response of Soil Respiration to Acid Rain in Forests of Different Maturity in Southern China. PLoS One 8(4). https://doi.org/10.1371/journal.pone.0062207

33. Likens GE, Driscoll CT, Buso DC (1996) Long-term effects of acid rain: Response and recovery of a forest ecosystem. Science 272:244-246. https://doi.org/10.1126/science.272.5259.244

34. Liu J, Zhou G, Zhang D (2007) Effects of acidic solutions on element dynamics in the monsoon evergreen broad-leaved forest at Dinghushan, China - Part 2: Dynamics of Fe, Cu, Mn and Al. Environ Sci Pollut Res 14:215-218. https://doi.org/10.1065/espr2006.08.337

35. Liu T, Yin G, Liu J, et al (2013) Impact of acid deposition on the main nutrients of subtropical forest Soil. Chinese J Appl Environ Biol 19, 255-261. https://doi.org/10.3724/SP.J.1145.2013.00255 (in Chinese with English abstract)

36. Louzao MJ, Leiros MC, Guitian F (1990) Study of buffering systems in soils from Galicia, N W spain. Water Air Soil Pollut 49:17-33. https://doi.org/10.1007/BF00279507

37. Lu X, Gilliam FS, Yu G, et al (2013) Long-term nitrogen addition decreases carbon leaching in a nitrogen-rich forest ecosystem. Biogeosciences 10:3931-3941. https://doi.org/10.5194/bg-10-39312013

38. Lu X, Mao Q, Gilliam FS, et al (2014) Nitrogen deposition contributes to soil acidification in tropical ecosystems. Glob Chang Biol 20:3790-3801. https://doi.org/10.1111/gcb.12665 
39. Lu X, Vitousek PM, Mao Q, et al (2021) Nitrogen deposition accelerates soil carbon sequestration in tropical forests. Proc Natl Acad Sci USA 118. https://doi.org/10.1073/pnas.2020790118

40. Masiello CA, Chadwick OA, Southon J, et al (2004) Weathering controls on mechanisms of carbon storage in grassland soils. Global Biogeochem Cycles 18(4). https://doi.org/10.1029/2004GB002219

41. Menefee SG, Overman OR, (1940) A Semimicro-Kjeldahl method for the determination of total nitrogen in milk. J Dairy Sci 23:1177-1185. https://doi.org/10.3168/jds.S0022-0302(40)92829-6

42. Meng $\mathrm{C}$, Tian D, Zeng $\mathrm{H}$, et al (2019) Global soil acidification impacts on belowground processes. Environ Res Lett 14. https://doi.org/10.1088/1748-9326/ab239c

43. Mikutta R, Lorenz D, Guggenberger G, et al (2014) Properties and reactivity of Fe-organic matter associations formed by coprecipitation versus adsorption: Clues from arsenate batch adsorption. Geochim Cosmochim Acta 144:258-276. https://doi.org/10.1016/j.gca.2014.08.026

44. Mueller KE, Eissenstat DM, Hobbie SE, et al (2012) Tree species effects on coupled cycles of carbon, nitrogen, and acidity in mineral soils at a common garden experiment. Biogeochemistry 111:601614. https://doi.org/10.1007/s10533-011-9695-7

45. Qiu Q, Chen X, Liang G, et al (2013) Effect of simulated acid deposition on chemistry of surface runoff in monsoon evergreen broad-leaved forest in Dinghushan. Acta Ecologica Sinica 33: 40214030. https://doi.org/10.5846/stxb201209111279 (in Chinese with English abstract)

46. Qiu Q, Wu J, Liang G, et al (2015) Effects of simulated acid rain on soil and soil solution chemistry in a monsoon evergreen broad-leaved forest in southern China. Environ Monit Assess 187:1-13. https://doi.org/10.1007/s10661-015-4492-8

47. Rasmussen C, Heckman K, Wieder WR, et al (2018) Beyond clay: towards an improved set of variables for predicting soil organic matter content. Biogeochemistry 137:297-306. https://doi.org/10.1007/s10533-018-0424-3

48. Raza S, Miao N, Wang P, et al (2020) Dramatic loss of inorganic carbon by nitrogen-induced soil acidification in Chinese croplands. Glob Chang Biol 26:3738-3751. https://doi.org/10.1111/gcb.15101

49. Ross DS, Matschonat G, Skyllberg U (2008) Cation exchange in forest soils: the need for a new perspective. Eur J Soil Sci 59:1141-1159. https://doi.org/10.1111/j.1365-2389.2008.01069.x

50. Schollenberger CJ (1927) A rapid approximate method for determining soil organic matter. Soil Sci 24: 65-68. https://doi.org/10.1097/00010694-192707000-00008

51. Soil Survey Staff (2014) Keys to Soil Taxonomy. 12th Edition. USDA-NRCS, Washington DC, 37-40.

52. Tang $X$, Zhao X, Bai Y, et al (2018) Carbon pools in China's terrestrial ecosystems: New estimates based on an intensive field survey. Proc Natl Acad Sci USA 115:4021-4026. https://doi.org/10.1073/pnas.1700291115

53. Tian D, Niu S (2015) A global analysis of soil acidification caused by nitrogen addition. Environ Res Lett 10(2):1714-1721. https://doi.org/10.1088/1748-9326/10/2/024019 
54. Viollier E, Inglett PW, Hunter K, et al (2000) The ferrozine method revisited: $\mathrm{Fe}(\mathrm{II}) / \mathrm{Fe}(\mathrm{III})$ determination in natural waters. Appl Geochemistry 15:785-790. https://doi.org/10.1016/S0883-2927(99)00097-9

55. Vitousek PM, Aber JD, Howarth RW, et al (1997) Human alteration of the global nitrogen cycle: Sources and consequences. Ecol Appl 7:737-750. https://doi.org/10.2307/2269431

56. Wagai R, Mayer LM (2007) Sorptive stabilization of organic matter in soils by hydrous iron oxides. Geochim Cosmochim Acta 71:25-35. https://doi.org/10.1016/j.gca.2006.08.047

57. Wu J, Liang G, Hui D, et al (2016) Prolonged acid rain facilitates soil organic carbon accumulation in a mature forest in Southern China. Sci Total Environ 544:94-102. https://doi.org/10.1016/j.scitotenv.2015.11.025

58. Xiao K, Zhou J, Liu X, et al (2013) Leaching of dissolved organic carbon (DOC) as affected by plant residue composition and soil pH. In, Xu, J., Wu, J., He, Y. (Eds.), Functions of natural organic matter in changing environment. Springer, Dordrecht, pp 475-478. https://doi.org/10.1007/978-94-007-56342_86

59. Xu JM, Yuan KN (1993) Dissolution and fractionation of calcium-bound and iron- and aluminumbound humus in soils. Pedosphere 1: 75-80.

60. Yan JH, Wang YP, Zhou GY, Zhang DQ (2006) Estimates of soil respiration and net primary production of three forests at different succession stages in South China. Glob Chang Biol 12:810821. https://doi.org/10.1111/j.1365-2486.2006.01141.x

61. Ye C, Chen D, Hall SJ, et al (2018) Reconciling multiple impacts of nitrogen enrichment on soil carbon: plant, microbial and geochemical controls. Ecol Lett 21:1162-1173. https://doi.org/10.1111/ele.13083

62. Yu G, Chen Z, Piao S, et al (2014) High carbon dioxide uptake by subtropical forest ecosystems in the East Asian monsoon region. Proc Natl Acad Sci USA 111:4910-4915. https://doi.org/10.1073/pnas.1317065111

63. Yu W, Weintraub SR, Hall SJ (2021) Climatic and Geochemical Controls on Soil Carbon at the Continental Scale: Interactions and Thresholds. Global Biogeochem Cycles 35. https://doi.org/10.1029/2020GB006781

64. Zamanian K, Zarebanadkouki M, Kuzyakov Y (2018) Nitrogen fertilization raises $\mathrm{CO} 2$ efflux from inorganic carbon: A global assessment. Glob Chang Biol 24:2810-2817. https://doi.org/10.1111/gcb.14148

65. Zhang X, Chai F, Wang S, et al (2010) Research progress of acid precipitation in China. Res Environ Sci 23: 527-532. https://doi.org/10.13198/j.res.2010.05.3.zhangxm.005 (in Chinese with English abstract)

\section{Figures}



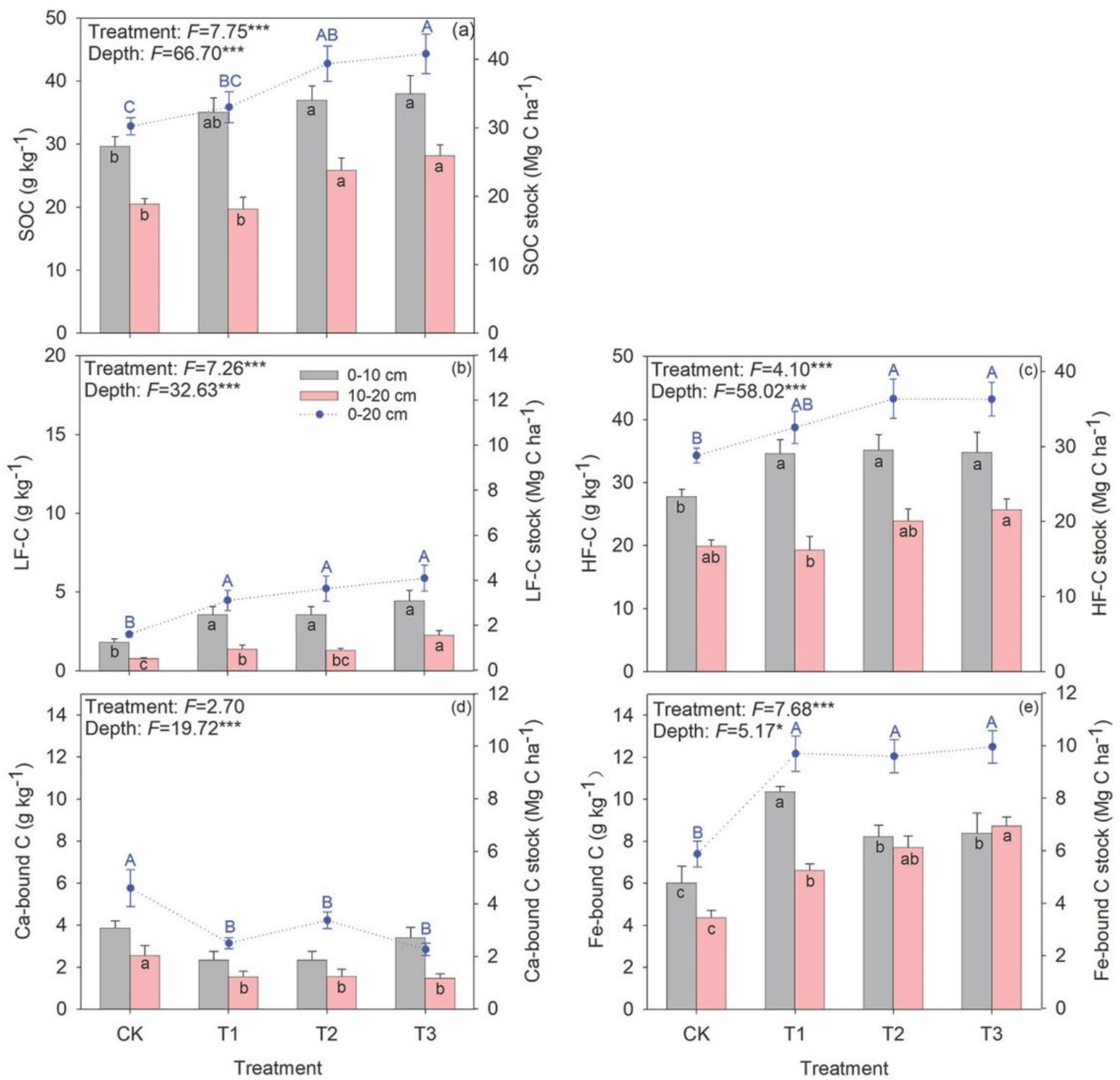

\section{Figure 1}

Responses of soil organic carbon fractions to the acidity treatments. The acidity treatments are: $\mathrm{CK}=$ control $(0 \mathrm{~mol} \mathrm{H}+\mathrm{ha}-1 \mathrm{yr}-1), \mathrm{T} 1=9.6 \mathrm{~mol} \mathrm{H}+\mathrm{ha}-1 \mathrm{yr}-1, \mathrm{~T} 2=32 \mathrm{~mol} \mathrm{H}+\mathrm{ha}-1 \mathrm{yr}-1$, and T3 = $96 \mathrm{~mol} \mathrm{H}+$ ha-1 yr-1. SOC, soil organic carbon; Fe-bound C, iron-bound organic carbon; Ca-bound C, calcium-bound organic carbon; LF-C and HF-C indicate the organic carbon in light fraction and heavy fraction, respectively. Error bars represent \pm standard errors. The columns and scatters represent soil organic carbon content and stock, respectively. Different lowercase letters within the columns in each soil layer 
denote significant difference $(p<0.05)$ in the contents of soil organic carbon fractions among the treatments. Different capital letters above the scatters denote significant difference $(p<0.05)$ in the stocks of soil organic carbon fractions among the treatments. As none of the interactions between treatment and depth on soil organic carbon fractions were significant, only main effects of treatment and soil depth are presented. $* * *$ and $* * *$ indicates that factors are significant at $p<0.05, p<0.01$ and $p<0.001$, respectively.
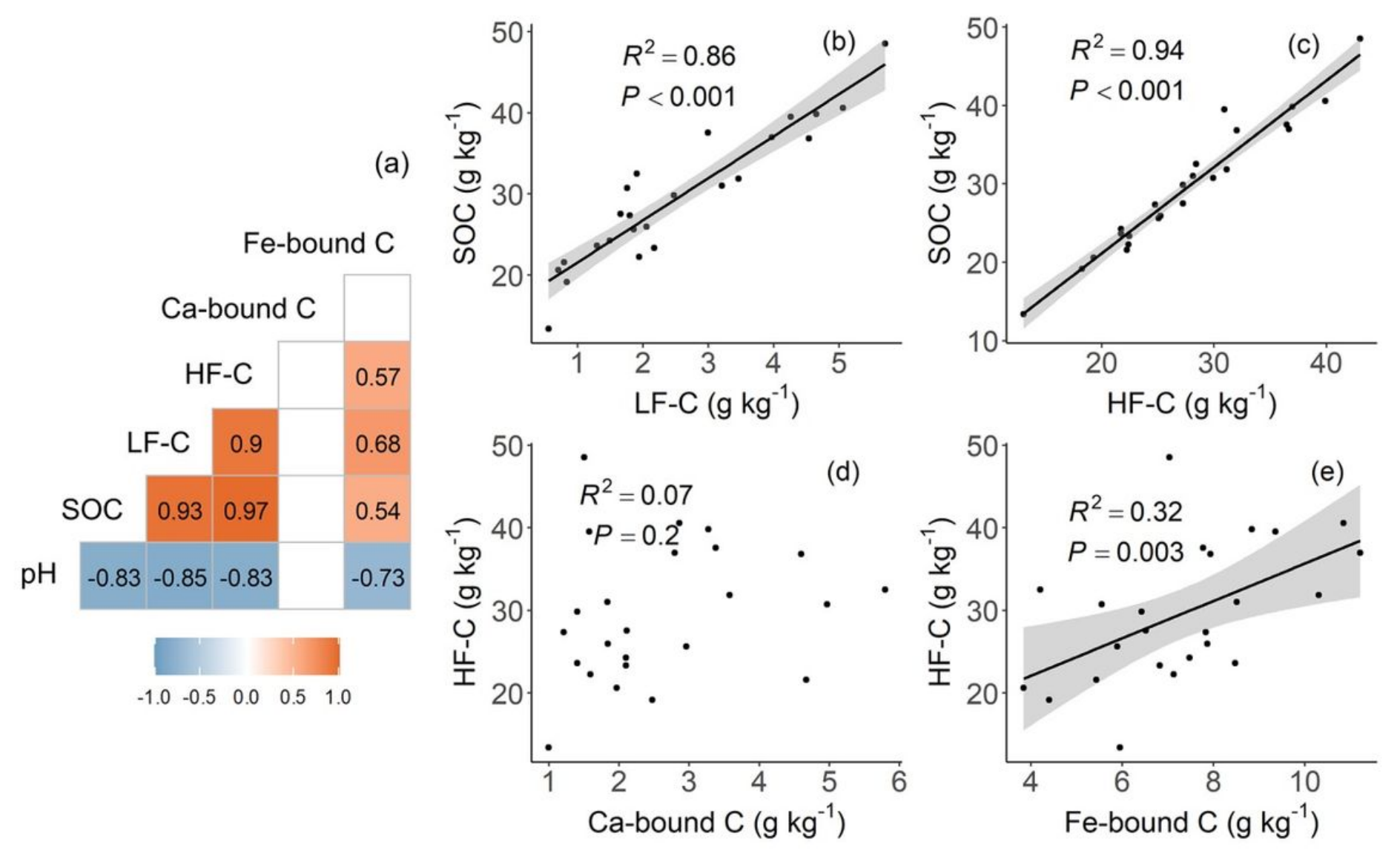

\section{Figure 2}

Pearson's correlation coefficients between soil pH and soil organic carbon fractions. SOC, soil organic carbon; Fe-bound C, iron-bound organic carbon; Ca-bound C, calcium-bound organic carbon; LF-C and HF$\mathrm{C}$ indicate the organic carbon in light fraction and heavy fraction, respectively. The red and blue squares indicate positive or negative correlations between parameters at a significance level of $a=0.05$ respectively. 

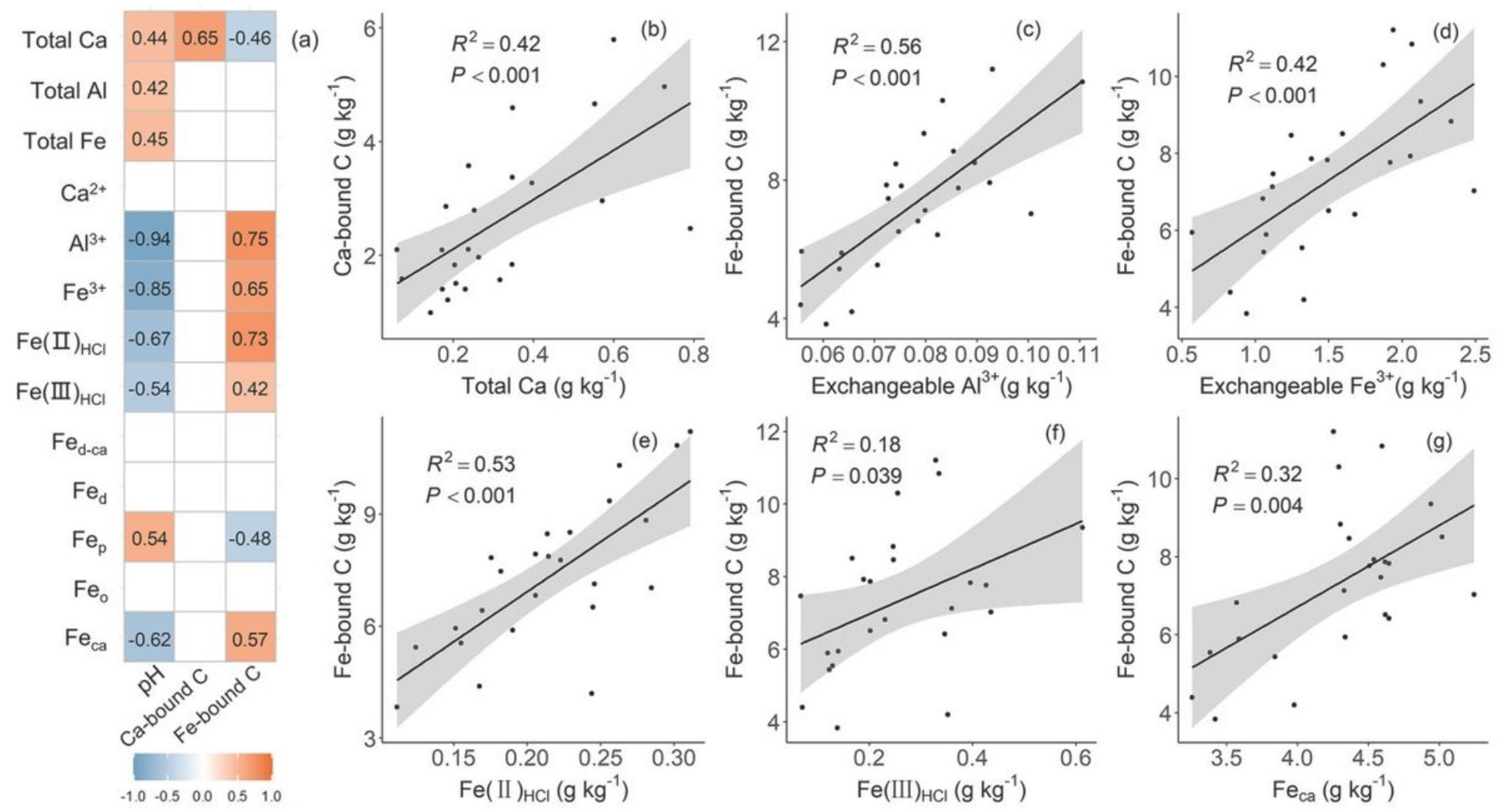

\section{Figure 3}

Pearson's correlation coefficients between soil pH, Ca-bound C, Fe-bound C and geochemical characteristics. Fe-bound C, iron-bound organic carbon; Ca-bound C, calcium-bound organic carbon; Feca, short-range-order Fe phases; Fed, Dithionite-bicarbonate-citrate extractable Fe phases; Fep, sodium pyrophosphate extractable Fe phases; Feo, ammonium oxalate extractable Fe phases. The red and blue squares indicate positive or negative correlations between parameters at a significance level of $a=0.05$ respectively. 


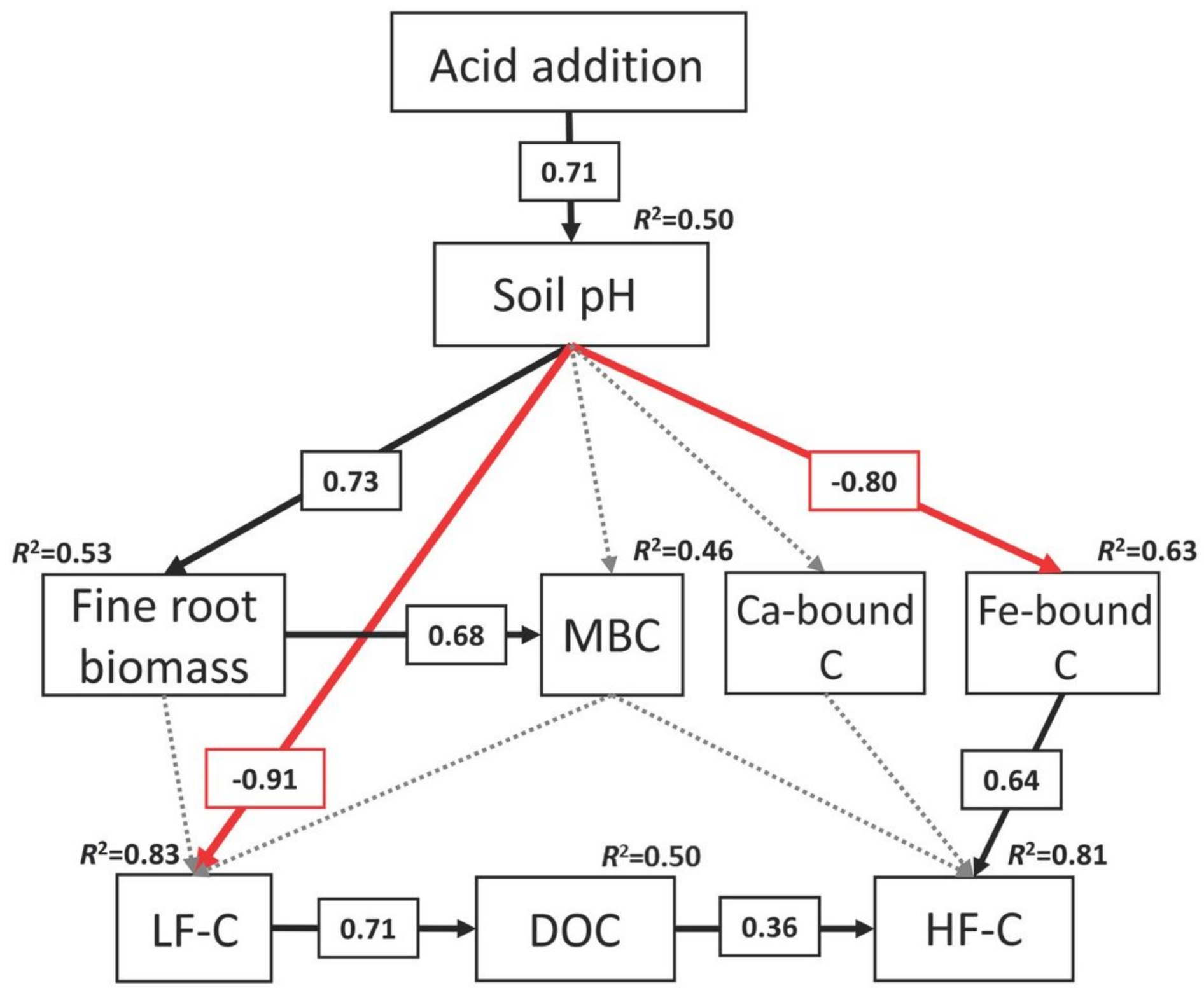

Figure 4

Structural equation model (SEM) analysis for the effects of the acidity treatment on soil organic carbon fractions via the pathways of soil acidification. Results of the model fitting: Chi-square $(X 2)=27.381, p=$ 0.055 , degree of freedom $(\mathrm{df})=18$, comparative fit index $(\mathrm{CFI})=0.942$, root square mean error of approximation $(\mathrm{RMSEA})=0.159$. Numbers at arrows are standardized path coefficients. Arrow thickness represents the strength of the relationships. Grey arrows indicate insignificant relationships $(p>0.05)$, while black and red arrows indicate significant positive and negative relationships, respectively $(p<0.05)$. In addition, R2 values associated with response variables indicate the proportion of variation explained by relationships with other variables. MBC, microbial biomass carbon; Fe-bound $C$, iron-bound organic carbon; Ca-bound C, calcium-bound organic carbon; LF-C and HF-C indicate the organic carbon in light fraction and heavy fraction, respectively. 